\title{
Effect of Natural Drying Methods on Moisture Content and Mass Change of Scots Pine Roundwood
}

\author{
Karol Tomczak $(\mathbb{B}$, Arkadiusz Tomczak *(-) and Tomasz Jelonek $(1)$ \\ Department of Forest Utilization, Faculty of Forestry, Poznań University of Life Sciences, Wojska Polskiego 71A, \\ 60-625 Poznań, Poland; karool.tomczak@gmail.com (K.T.); tomasz.jelonek@up.poznan.pl (T.J.) \\ * Correspondence: arkadiusz.tomczak@up.poznan.pl
}

Received: 6 May 2020; Accepted: 10 June 2020; Published: 11 June 2020

\begin{abstract}
This study evaluated changes in mass and the moisture content of stored summer-harvested Scots pine small diameter roundwood subject to different types of preparation and storage (drying methods). Small diameter roundwood was naturally dried for three months, from 15 June to 15 September 2018. We analyzed three methods of preparation and storage. First, logs $1.2 \mathrm{~m}$ in length were stored and air-dried in piles (C). In the second case, a transpirational drying method was used (W). Thirdly and finally, we used air-drying for logs with lengths between 9.6 and $14.4 \mathrm{~m}$ (L) stored in the harvesting area. Within three months, the moisture content of the logs stored in piles decreased by 22.9 percentage points. With the transpirational drying method $(\mathrm{W})$ the decrease in moisture content was 10.0 percentage points. In scenario $\mathrm{L}$, at the end of the storage period the moisture content was lower by 15 percentage points. Within three months, the density of the roundwood stored in piles decreased to $700 \mathrm{~kg} / \mathrm{m}^{3}$, which is about $140 \mathrm{~kg} / \mathrm{m}^{3}$ more than in scenarios W and L. Cutting stemwood into short segments and storing it in a pile appears to have positive effects on drying performance. Overall, this study shows that, for Scots pine wood, air-drying is a better method than transpirational drying.
\end{abstract}

Keywords: transpirational drying; air-drying; energywood; small diameter roundwood

\section{Introduction}

Scots pine is a species that occurs in about $58 \%$ of the total area of forests in Poland. It is estimated that in the next 10 years, pine stands aged from 21 to 80 years will provide approximately 155 million $\mathrm{m}^{3}$ of small-diameter roundwood. Transportation of this quantity of timber will entail a large number of vehicle journeys. Transport is often the most expensive phase of timber harvesting operations [1-3]. The final transport costs depend on the type of truck (payload, gross vehicle mass, fuel consumption), transportation distance, and country. In Poland the gross vehicle weight (GVW)—timber load mass and total mass of a vehicle-cannot exceed $40,000 \mathrm{~kg}$ and therefore trucks used to transport timber are often not loaded to their full volume. To improve the efficiency of use of trucks, and thus reduce transport costs, management of wood moisture content (MC) may be applied [1,4-6].

Natural drying is a simple way of reducing the MC and weight of raw material, and does not require substantial financial investment, because it can be carried out in the harvesting area [6-11]. Potential costs can be related to wood degradation by insects or fungi (dry matter loss). But this depends on climatic conditions and storage time [12]. In practice, to emphasize the differences, various names of natural drying are used. The drying of whole trees (felled trees are left on the ground with its crown intact) is called transpirational drying (also called biological drying, leaf seasoning, leaf felling, sour felling) [13]. Whereas drying of roundwood or chips is often called air-drying [4]. All methods are based on natural mechanisms. The effectiveness of transpirational drying depends on the intensity of evaporation of the above-ground part of the plant [14]. More water evaporates with low air humidity, 
but at high air humidity the intensity of the process decreases [15]. Air-drying is based on the same

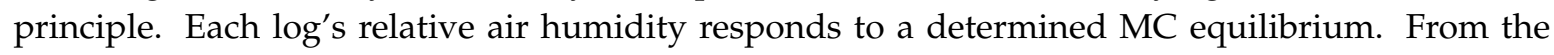
physical standpoint, the equilibrium of wood MC is a state in which the vapor pressure in the wood is equal to the vapor pressure in the air. Once the equilibrium has been achieved the exchange of moisture between the material and the environment ceases. Hence, the relative humidity of air is a significant variable in modeling the natural drying process $[8,16]$. First to vaporize is the water from the outer layers of the material; subsequently, the rate of drying decreases as the water from the deeper layers of the material evaporates (inner diffusion). The dynamics of inner diffusion are influenced heavily by the structure of the material and its surface. In logs, evaporation is limited to the log ends, because the bark substantially limits the drying process [17-19]. By splitting a larger drying surface is achieved, and in this way slower moisture content transport in radial direction is balanced [5].

Natural drying methods are significant mainly in summertime. However, there are situations when the MC of stored wood increases. This may happen during and after heavy precipitation, but the phenomenon of rewetting most often takes place in autumn and winter [18,20,21]. According to Hakkila [13] transpirational drying of small-sized conifers is significant from May onward. Conifers require the whole summer season to dry well. Provided that felling takes place sufficiently early, the MC of Scots pine trees 5 to $10 \mathrm{~cm}$ in diameter usually reaches about $35-45 \%$, although it may exceptionally fall to $30 \%$ [13].

Drying takes place through transpiration as long as the foliage maintains its activity. For this reason, the most rapid drying occurs during the first weeks after a tree is felled [13,22]. McMinn [23] studied transpirational drying for three tree species in Georgia. For all species, a large proportion of moisture loss occurred during the first three weeks after felling. The same storage period is recommended for Pinus taeda by Rogers [24]. Cutshall et al. [25] for 14-year-old loblolly pine recommended a four-week drying period.

A series of factors influence the speed of drying, first of all a climatic conditions, the season of the year, method of storage, species and size of the piece [9,13,26-29]. Wang et al. [14] compared changes in the moisture content of poplar trees with and without canopies and where the water supply from the roots was blocked. The results indicate that transpiration is the main driving force that reduces water during physiological drying, and the main factors that influence this process are the air conditions. Tomczak et al. [30] compared two methods of drying beech energy logwood. Within 14 days of establishment the logs stored in piles lost about $6 \%$ of their weight (an indicator of change in moisture content), while for energywood undergoing transpirational drying the loss was about $10 \%$. Results obtained for Douglas fir showed $6 \%$ greater moisture loss in the crowns of stems that retained limbs after felling compared to stems with limbs removed after harvesting. Additionally, moisture loss rate increased as stem size decreased [31]. Generally small diameter logs dry easier and faster than large logs [32-35]. In wood in bark moisture is transported primarily in the longitudinal direction, to the open cutting area. For this reason, the drying effect also depends on the length of the log [18].

Nurmi and Hillebrand [20] showed that Scots pine multi-tree harvested stemwood with no limbs loss MC equally as whole trees in both roadside and in-stand trials. This is because the processing of multi-tree bunches caused some debarking to take place. As a result, the transpirational drying capability of whole trees was equalized by the evaporation of moisture via the open wood surface. Both assortments reached MC below 30\% in in-stand conditions during one summer's seasoning. This indicates that the transpirational drying of Scots pine is same effective in comparison with air-drying, if open wood surface (without bark) is big enough. Therefore, it can be assumed that Scots pine short logwood to be a material that can benefit the most from storage in piles, and that the transpirational drying of Scots pine is less effective in comparison with air-drying. Accordingly, the main objective of this study was to compare transpirational and air-drying of Scots pine small-diameter roundwood, as well as mixed methods with different lengths of the drying period in piles, because the literature indicates that transpirational drying is only effective at the beginning of storage. Air-drying was performed for two lengths of logs: $1.2 \mathrm{~m}$ and between 9.6 and $14.4 \mathrm{~m}$. 


\section{Materials and Methods}

\subsection{Site Selection and Preparation of Model Trees}

The research was conducted in the middle part of the area of the Scots pine's natural occurrence. The material was collected from one tree stand in the area known as Notecka Forest (Poland) $\left(52^{\circ} 40^{\prime} 31.069^{\prime \prime} \mathrm{N} ; 16^{\circ} 6^{\prime} 18.055^{\prime \prime} \mathrm{E}\right)$. The stand where the research was conducted is a 50-year-old fresh coniferous forest, Psamment podzol soil, Calamagrostio arundinaceae-Quercetum association.

Data were collected monthly from 15 June to 15 September 2018 (seven scenarios were followed). The model trees were determined by the dendrometric method of Urich, variant I [36]. For this method diameter at breast height (DBH) of all trees selected to be felled for commercial thinning were measured and divided their on three sub-classes, with an equal number of trees. For each diameter sub-classes seven model trees were chosen. In each scenario, one model tree had a DBH between 9 and $11 \mathrm{~cm}$. The second tree between 12 and $14 \mathrm{~cm}$, and the third model tree between 15 and $18 \mathrm{~cm}$. Generally, 21 sample trees were chosen, three per scenario. The average height was $18 \mathrm{~m}$. All model trees were felled in the same day.

\subsection{Climatic Data}

The storage trial took place outdoors, with all treatments exposed to the same climatic conditions. Climatic parameters such as precipitation, relative air humidity and air temperature were recorded during the entire test. Air temperature was measured to an accuracy of $1{ }^{\circ} \mathrm{C}$, humidity to $1 \%$, and rainfall to $0.01 \mathrm{l} / \mathrm{m}^{2}$. Data were recorded using a mobile meteorological station (Hyundai WSP $3080 \mathrm{R}$ WIND). Measuring components were installed at a height of $1.5 \mathrm{~m}$ above ground. The instrument was located approximately $800 \mathrm{~m}$ from the storage site. Data was collected continuously over the duration of the study at 30 min intervals. The data was then structured to represent daily means. For visualization climate data we used the R software (R Core Team, 2020).

\subsection{Drying Scenarios}

Three methods of log preparation and storage (drying) were analyzed:

(1) Scenario C: logs (1.2 m length) were stored and air-dried in piles;

(2) Scenario W: transpirational drying method for felled trees with branches not removed (whole trees), storage duration: $1\left(\mathrm{~W}_{1}\right), 2\left(\mathrm{~W}_{2}\right)$, or 3 months $\left(\mathrm{W}_{3}\right)$;

(3) Scenario L: air-drying method for felled trees with branches removed, stemwood length between 9.6 and $14.4 \mathrm{~m}$, storage duration: $1\left(\mathrm{~L}_{1}\right), 2\left(\mathrm{~L}_{2}\right)$, or 3 months $\left(\mathrm{L}_{3}\right)$.

Additionally, for scenarios $\mathrm{W}$ and $\mathrm{L}$, when the storage duration had elapsed, the trunks were cut into logs $1.2 \mathrm{~m}$ in length and the air-drying method was analyzed. Logs stored in piles were weighed every month until the end of the experiment (Figure 1). 


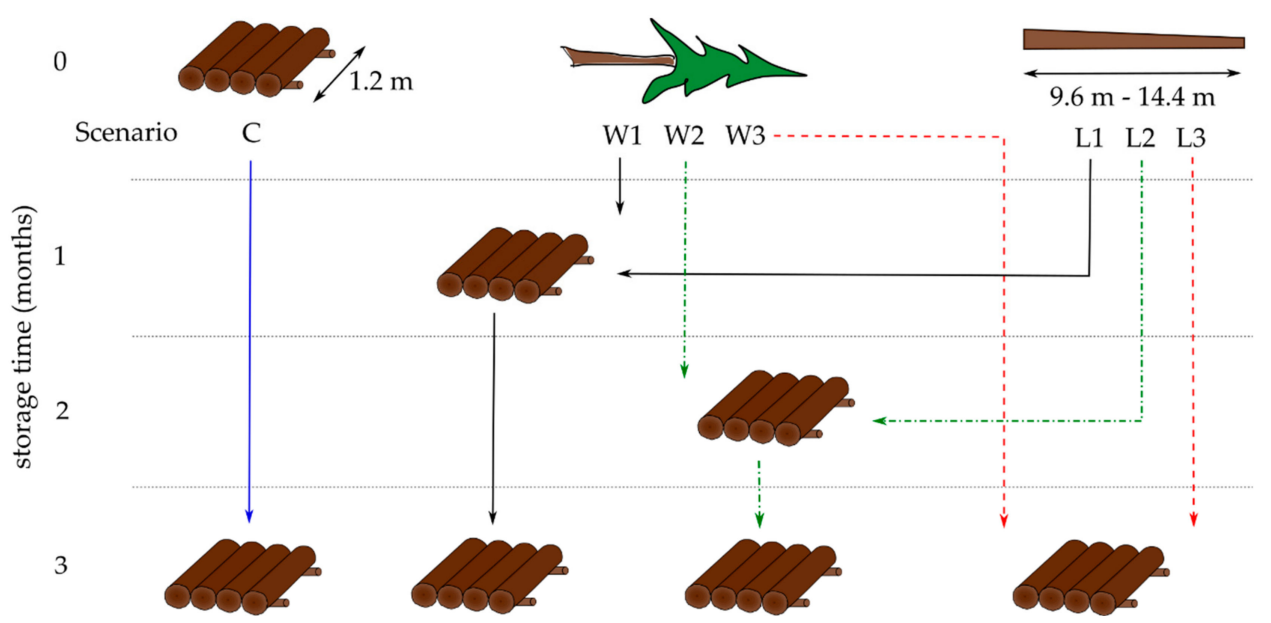

Figure 1. Scheme for drying scenarios: C-logs stored and air-drying in pile during three months; $\mathrm{W}_{1}$-one month transpirational drying and two months in pile; $\mathrm{L}_{1}$-one month air-drying for stemwood and two months in pile; $\mathrm{W}_{2}$ - two months transpirational drying and one month in pile; $\mathrm{L}_{2}$ - two months air-drying for stemwood and one month in pile; $\mathrm{W}_{3}$ - transpirational drying during three months; $\mathrm{L}_{3}$-stemwood air-drying during three months.

The logs was stored at the logging site.

\subsection{Characteristics of the $\log s$}

During the experiment, 206 logs in total were harvested by conventional, motor-manual logging methods, with minimal bark damage.

The diameter outside bark at the ends of the logs was measured using a caliper with $0.1 \mathrm{~cm}$ accuracy. The measurements were performed twice: minimum and maximum. In the next step the areas of the large and small ends of the logs were calculated using a mathematical formula for a surface area of a circle. The length of the logs was measured using a tape with $1 \mathrm{~cm}$ accuracy. The volume (V) of the logs was estimated by Smalian's Equation (1):

$$
\mathrm{V}=(\mathrm{G} 0+\mathrm{Gl}) / 2 \times 1
$$

where:

$\mathrm{V}$ is the volume of the $\log \left(\mathrm{m}^{3}\right)$;

G0 is the area of the large end of the $\log \left(\mathrm{m}^{2}\right)$;

G1 is the area of the small end of the $\log \left(\mathrm{m}^{2}\right)$;

1 is the length of the $\log (\mathrm{m})$.

To measure the mass of the logs $(\mathrm{m})$, industrial platform scales with a maximum capacity of $300 \mathrm{~kg}$ were used. The weight was measured to an accuracy of $0.1 \mathrm{~kg}$. The logs stored in piles (C) were weighed four-times, at the beginning of the experiment, and every month (i.e., the initial log weight is given as $100 \%$ and subsequent measurements is known as the amount of water loss). In scenarios $W_{1}$ and $L_{1}$ the logs were weighed three-times. In scenarios $W_{2}$ and $L_{2}$ the logs were weighed twice and in scenarios $\mathrm{W}_{3}$ and $\mathrm{L}_{3}$ once when the stemwood was cut into $1.2 \mathrm{~m}$ logs. In the next step the log density (Q) (i.e., known as the mass change and water loss per $1 \mathrm{~m}^{3}$ of roundwood) was estimated. 


\subsection{Sampling Procedure (Moisture Content-MC)}

To determine the initial moisture content, a different number of samples (wood disks) was taken from the trunks, according to the scenario:

(1) Scenario C: wood disks were collected along the trunk, from each segment, every $1.2 \mathrm{~m}$;

(2) Scenario W: wood disks were collected only from the bottom part of the tree trunk;

(3) Scenario L: wood disks were collected from both the bottom and top of the trunk.

Additionally, for scenarios $\mathrm{W}$ and $\mathrm{L}$, when the storage duration had elapsed, wood disks were collected along the trunk, from each segment, every $1.2 \mathrm{~m}$. At the end of the experiment, wood disks were collected from each log, at half-length (Figure 2).

0
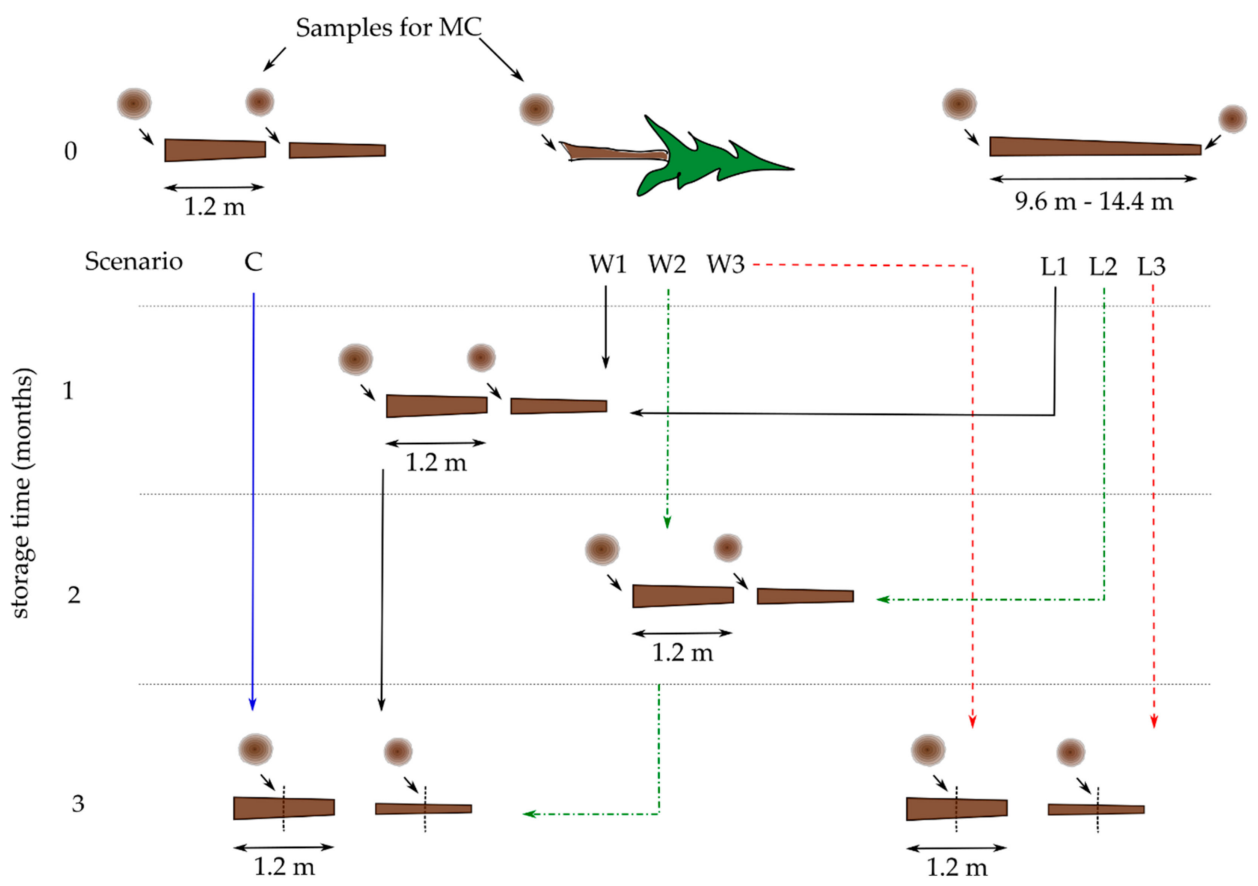

Figure 2. Sampling procedure (MC) for scenarios: C-logs stored and air-drying in pile during three months; $\mathrm{W}_{1}$-one month transpirational drying and two months in pile; $\mathrm{L}_{1}$-one month air-drying for stemwood and two months in pile; $\mathrm{W}_{2}$ - two months transpirational drying and one month in pile; $\mathrm{L}_{2}$ - two months air-drying for stemwood and one month in pile; $\mathrm{W}_{3}$ - transpirational drying during three months; $\mathrm{L}_{3}$ —stemwood air-drying during three months.

Immediately after collection and marking of the samples, they were weighed green $\left(\mathrm{m}_{\mathrm{w}}, 0.01 \mathrm{~g}\right.$ accuracy). In the laboratory, the samples were oven dried at $105^{\circ} \mathrm{C}\left(\mathrm{m}_{\mathrm{s}}\right)$ [37]. The relative moisture content (MC) was estimated by Equation (2):

$$
\mathrm{MC}=\left(\mathrm{m}_{\mathrm{w}}-\mathrm{m}_{\mathrm{s}}\right) / \mathrm{m}_{\mathrm{w}} \times 100
$$

where:

$\mathrm{m}_{\mathrm{W}}$ is the mass of green wood $(\mathrm{g})$;

$\mathrm{m}_{\mathrm{s}}$ is the mass of dry wood $(\mathrm{g})$;

$\mathrm{MC}$ is the wood moisture content (\%).

\subsection{Statistical Analyses}

In order to compare mass, MC, and density with respect to the experimental variables, in the first step, the Lilliefors test was used to examine the normal distribution of data. The data in the analysed 
groups were of a different quantity and had no normal distribution. As a result of this, three or more dependent observations (mass and density of logs in scenarios, between months of storage) using Friedman's test was carried out. To discover which data were significantly different from each other, the Nemenyi post hoc test was used. For two dependent observations (MC and results from scenarios $\mathrm{W}_{2}$ and $\mathrm{L}_{2}$ for mass and density) Wilkoxon's test was carried out. In order to compare data between scenarios (independent observations) the non-parametric Kruskal Wallis test was carried out, followed by a Dunn test for the multiple comparisons of means from each group of data. Statistical inference was performed at significance level $\alpha=0.05$. The program Statistica 13.1 (TIBCO Software Inc., Palo Alto, CA, USA) and package R (R Core Team, 2020) was used for the calculations.

\section{Results}

\subsection{Climate}

During storage time, precipitation was experienced on 22 days (from 0.1 to $16.2 \mathrm{~mm}$ ) and on 70 days there was no rain. The average precipitation was $5 \mathrm{~mm}$. The highest air temperature was $34.7^{\circ} \mathrm{C}$, the lowest was $1.4^{\circ} \mathrm{C}$, and the average was $17.3^{\circ} \mathrm{C}$. The largest daily change was in air humidity, which ranged between $37 \%$ and about $100 \%$. The average air humidity during the experiment was $68 \%$. The most favorable conditions for the drying of wood were recorded in August, when the average temperature was $19^{\circ} \mathrm{C}$ and there was little precipitation (Figure 3).
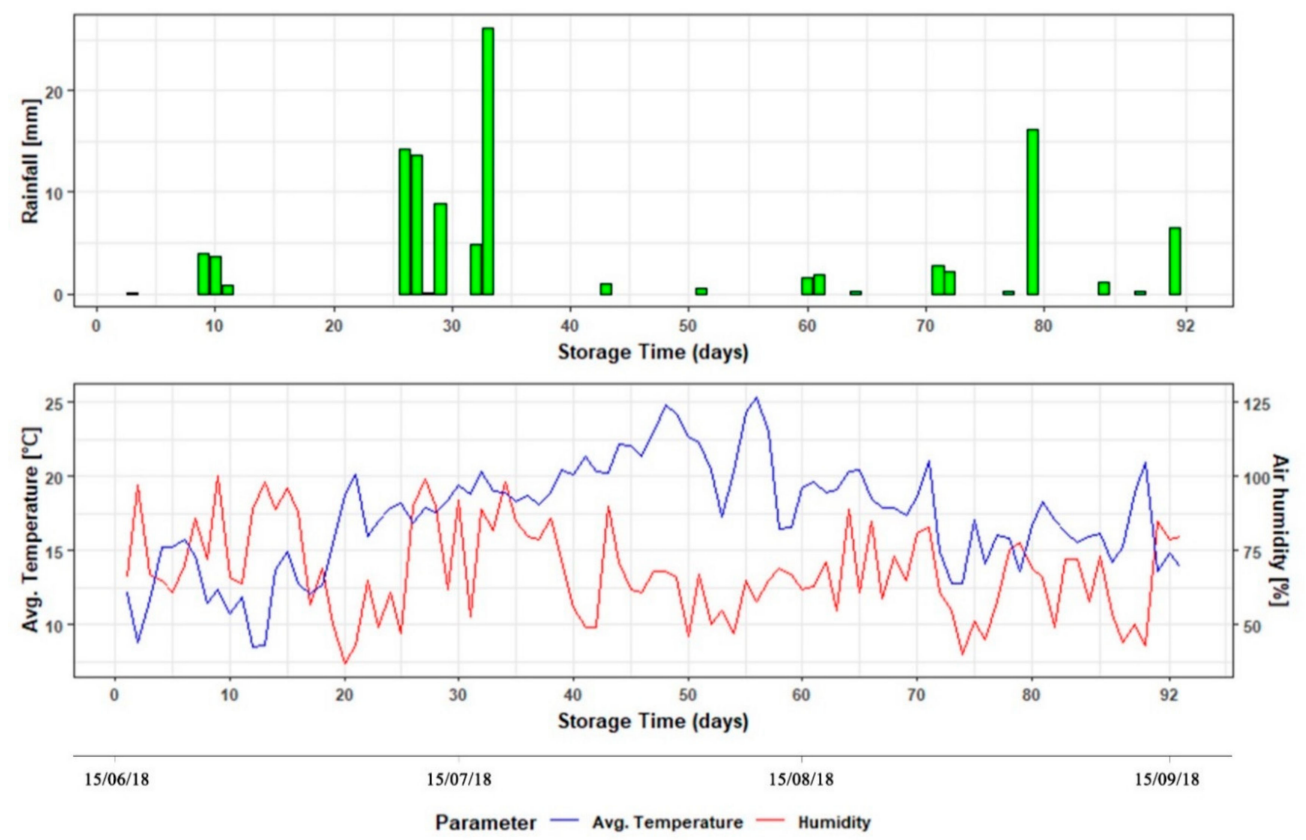

Figure 3. Weather data recorded during the storage period.

\subsection{Mass}

The mass of logs stored in piles (C) was lower by $11.3 \%$ after one month and by $24.0 \%$ after two months than on the day of harvesting. Within three months, the mean mass of logs stored in piles decreased by approximately $36 \%$. In other scenarios differences between months were very similar to the changes observed in scenario $C$. In each scenario the differences in mass between consecutive stages of the experiment (storage times) were statistically significant, while there were no statistically significant differences in logs mass between scenarios $(p<0.05)$.

In the first month the mass of logs stored in piles (C) was lower by $1.5 \%$ than that of logs dried by transpiration $\left(\mathrm{W}_{1}\right)$, and lower by $6.2 \%$ than in scenario $\mathrm{L}_{1}$. After two months the density of the logs 
stored in piles (C) was lower only between scenarios $\mathrm{W}_{2}(2.6 \%)$ and $\mathrm{L}_{2}(12.5 \%)$. After three months the mass of the logs stored in piles (C) was lower by $21.4 \%$ than in scenario $\mathrm{W}_{3}$ and lower by $13.2 \%$ than in scenario $\mathrm{L}_{3}$. Differences between scenarios were statistically insignificant (Table 1).

Table 1. Mean volume (V) and mass of logs according to scenarios and storing duration in pile.

\begin{tabular}{|c|c|c|c|c|c|c|}
\hline Scenario & $\mathrm{n}$ & $\mathrm{V}\left[\mathrm{m}^{3}\right] \pm \mathrm{SD}$ & \multicolumn{4}{|c|}{ Mass $[\mathrm{kg}] \pm$ SD (Storage Time in Pile-Months) } \\
\hline $\mathrm{C}$ & 29 & $0.011 \pm 0.005$ & $\begin{array}{c}11.23 \pm 4.81_{1,2,3} \\
(0)\end{array}$ & $\begin{array}{c}10.09 \pm 4.92_{0,2,3} \\
\text { (1) }\end{array}$ & $\begin{array}{c}8.95 \pm 5.02_{0,1,3} \\
\text { (2) }\end{array}$ & $\begin{array}{c}7.99 \pm 4.41_{1,2,3} \\
\text { (3) }\end{array}$ \\
\hline $\mathrm{W}_{1}$ & 31 & $0.011 \pm 0.005$ & & $\begin{array}{c}10.24 \pm 3.92_{2,3} \\
(0)\end{array}$ & $\begin{array}{c}8.92 \pm 3.77_{1,3} \\
\text { (1) }\end{array}$ & $\begin{array}{c}7.98 \pm 3.67_{1,2} \\
\text { (2) }\end{array}$ \\
\hline $\mathrm{L}_{1}$ & 32 & $0.011 \pm 0.005$ & & $\begin{array}{c}10.76 \pm 4.65_{2,3} \\
(0)\end{array}$ & $\begin{array}{c}9.39 \pm 4.54_{1,3} \\
(1)\end{array}$ & $\begin{array}{c}8.91 \pm 4.45_{1,2} \\
\text { (2) }\end{array}$ \\
\hline $\mathrm{W}_{2}$ & 26 & $0.010 \pm 0.004$ & & & $\begin{array}{c}9.19 \pm 3.44_{3} \\
(0)\end{array}$ & $\begin{array}{c}8.25 \pm 3.31_{2} \\
(1)\end{array}$ \\
\hline $\mathrm{L}_{2}$ & 29 & $0.011 \pm 0.005$ & & & $\begin{array}{c}10.23 \pm 4.72_{3} \\
(0)\end{array}$ & $\begin{array}{c}9.28 \pm 4.62_{2} \\
\text { (1) }\end{array}$ \\
\hline $\mathrm{W}_{3}$ & 30 & $0.012 \pm 0.006$ & & & & $\begin{array}{c}10.17 \pm 4.07 \\
(0)\end{array}$ \\
\hline $\mathrm{L}_{3}$ & 29 & $0.011 \pm 0.005$ & & & & $\begin{array}{c}9.20 \pm 4.60 \\
(0)\end{array}$ \\
\hline
\end{tabular}

Note: Different subscripts denote a statistically significant difference between storage time (months). Scenarios: $\mathrm{C}$-logs stored and air-drying in pile during three months; $\mathrm{W}_{1}$ - one month transpirational drying and two months in pile; $\mathrm{L}_{1}$-one month air-drying for stemwood and two months in pile; $\mathrm{W}_{2}$ - two months transpirational drying and one month in pile; $\mathrm{L}_{2}$ - two months air-drying for stemwood and one month in pile; $\mathrm{W}_{3}$-transpirational drying during three months; $\mathrm{L}_{3}$ - stemwood air-drying during three months.

\subsection{Moisture Content}

Initial moisture content was from $45.1 \%\left(\right.$ scenario $\mathrm{W}_{3}$ ) to $51.2 \%$ (scenario $\mathrm{L}_{2}$ ). Within each month moisture content decreased about several percent points. Within three months, scenario $\mathrm{C}$ and selected mixed methods (scenarios $\mathrm{W}_{1}, \mathrm{~L}_{1}$ and $\mathrm{W}_{2}, \mathrm{~L}_{2}$ ), finally reduced the $\mathrm{MC}$ to below $30 \%$. The results of drying by different methods over three months were often similar. Statistically significant differences were found only between scenarios $W_{1}$ and $L_{1}$, which at the beginning of the experiment differed in moisture content (by several percentage points). Statistically significant differences were found between storage time (months) for all scenarios $(p<0.05)$ (Table 2).

Table 2. MC of logs according to scenarios and storage time.

\begin{tabular}{|c|c|c|c|c|}
\hline \multirow{2}{*}{ Scenario } & \multirow{2}{*}{ Initial Moisture Content (iMC) } & \multicolumn{3}{|c|}{ Storage Time-Months Mean $[\%] \pm$ SD } \\
\hline & & 1 & 2 & 3 \\
\hline $\mathrm{C}$ & $49.6 \pm 4.9_{3}$ & - & - & $26.7 \pm 4.9_{0}$ \\
\hline $\mathrm{W}_{1}$ & $45.2 \pm 3.1$ & $41.9 \pm 9.4^{\mathrm{L} 1}$ & - & $29.9 \pm 10.2_{1}$ \\
\hline $\mathrm{L}_{1}$ & $50.3 \pm 2.9$ & $47.0 \pm 7.2 \mathrm{~W} 1_{3}$ & - & $26.5 \pm 11.2_{1}$ \\
\hline $\mathrm{W}_{2}$ & $49.3 \pm 2.1$ & - & $38.8 \pm 12.8_{3}$ & $29.9 \pm 8.8_{2}$ \\
\hline $\mathrm{L}_{2}$ & $51.2 \pm 3.3$ & - & $34.9 \pm 12.9_{3}$ & $26.8 \pm 6.8_{2}$ \\
\hline $\mathrm{W}_{3}$ & $45.1 \pm 7.1$ & - & - & $35.1 \pm 14.0$ \\
\hline $\mathrm{L}_{3}$ & $49.6 \pm 6.9$ & - & - & $33.8 \pm 11.0$ \\
\hline
\end{tabular}

Note: different superscripts denote a statistically significant difference between scenarios. Different subscripts denote a statistically significant difference between storage time (months). Scenarios: C-logs stored and air-drying in pile during three months; $\mathrm{W}_{1}$ - one month transpirational drying and two months in pile; $\mathrm{L}_{1}$ - one month air-drying for stemwood and two months in pile; $\mathrm{W}_{2}$ - two months transpirational drying and one month in pile; $\mathrm{L}_{2}$ - two months air-drying for stemwood and one month in pile; $\mathrm{W}_{3}$ - transpirational drying during three months; $\mathrm{L}_{3}$-stemwood air-drying during three months.

\subsection{Density}

The density of logs (for specific MC at measure day) stored in piles (C) was lower by $12.2 \%$ after one month and by $26.3 \%$ after two months than on the day of harvesting. Over the entire period of storage (three months) the density of these logs decreased by approximately $37 \%$. In the mixed scenarios, after the logs were cut into short segments and placed in a pile, the changes in density were 
similar to those obtained in scenario $C$. Between the first and second months of storage the log density for particular scenarios decreased by $14.1 \%(\mathrm{C}), 14.7 \%\left(\mathrm{~W}_{1}\right)$ and $14.1 \%\left(\mathrm{~L}_{1}\right)$. Further decreases were observed between the second and third months of storage. In this period the logs dried at a slower rate. In scenario $\mathrm{C}$ the density decreased by $10.4 \%$; the decreases in other scenarios were $11.7 \%\left(\mathrm{~W}_{1}\right)$, $10.7 \%\left(\mathrm{~L}_{1}\right), 11.4 \%\left(\mathrm{~W}_{2}\right)$ and $10.3 \%\left(\mathrm{~L}_{2}\right)$. In each scenario the differences in density between consecutive stages of the experiment (storage times) were statistically significant $(p<0.05)$.

In the first month the density of logs stored in piles (C) was lower by $6.3 \%$ than that of logs dried by transpiration $\left(\mathrm{W}_{1}\right)$, and lower by $5.6 \%$ than that of logs with lengths between 9.6 and $14.4 \mathrm{~m}$ subjected to air-drying $\left(\mathrm{L}_{1}\right)$. The differences were statistically significant between scenarios $\mathrm{C}$ and $\mathrm{W}_{1}(p<0.05)$. After two months the density of the logs stored in piles $(C)$ was lower by $13.3 \%$ than in scenario $W_{2}$ and lower by $11.9 \%$ than in scenario $L_{2}$. The differences were statistically significant between scenarios $\mathrm{C}$ and $\mathrm{W}_{2}, \mathrm{C}$ and $\mathrm{L}_{2}$, and not statistically significant between scenarios $\mathrm{C}$ and $\mathrm{W}_{1}, \mathrm{C}$ and $\mathrm{L}_{1}(p<0.05)$. After three months the density of the logs stored in piles $(C)$ was lower by $20.1 \%$ than in scenario $\mathrm{W}_{3}$ and lower by $10.4 \%$ than in scenario $\mathrm{L}_{3}$. In this case was a statistically significant difference between scenarios $\mathrm{C}$ and $\mathrm{W}_{2}, \mathrm{~L}_{2}, \mathrm{~W}_{3}, \mathrm{~L}_{3}(p<0.05)$ (Table 3).

Table 3. Density of logs according to scenarios and storage time.

\begin{tabular}{|c|c|c|c|c|}
\hline \multirow{2}{*}{ Scenario } & \multicolumn{4}{|c|}{ Storage Time-Months Mean $\left[\mathrm{kg} / \mathrm{m}^{3}\right] \pm \mathrm{SD}$} \\
\hline & 0 & 1 & 2 & 3 \\
\hline C & $1028 \pm 73.5_{1,2,3}$ & $903 \pm 50.5^{\mathrm{W} 1}{ }_{0,2,3}$ & $776 \pm 95.4^{\mathrm{W} 2, \mathrm{~L} 2} 0,1,3$ & $695 \pm 86.4^{\mathrm{W} 2, \mathrm{~L} 2, \mathrm{~W} 3, \mathrm{~L} 3{ }_{0,1,2}}$ \\
\hline $\mathrm{W}_{1}$ & & $963 \pm 66.4 \mathrm{C}_{2,3}$ & $827 \pm 55.2_{1,3}$ & $730 \pm 80.3_{1,2}$ \\
\hline $\mathrm{L}_{1}$ & & $957 \pm 85.9_{2,3}$ & $816 \pm 97.7_{1,3}$ & $728 \pm 103 \cdot 1_{1,2}$ \\
\hline $\mathrm{W}_{2}$ & & & $895 \pm 75.1 C_{3}$ & $787 \pm 80.9 C_{2}$ \\
\hline $\mathrm{L}_{2}$ & & & $881 \pm 78.9^{C_{3}}$ & $789 \pm 105.0 \mathrm{C}_{2}$ \\
\hline $\mathrm{W}_{3}$ & & & & $835 \pm 96.6^{C^{2}}$ \\
\hline $\mathrm{L}_{3}$ & & & & $806 \pm 69.4^{C}$ \\
\hline
\end{tabular}

Note: different superscripts denote a statistically significant difference between scenarios. Different subscripts denote a statistically significant difference between storage time (months). Scenarios: C-logs stored and air-drying in pile during three months; $W_{1}$-one month transpirational drying and two months in pile; $\mathrm{L}_{1}-\mathrm{one}_{\mathrm{mon}}$ air-drying for stemwood and two months in pile; $\mathrm{W}_{2}$ - two months transpirational drying and one month in pile; $\mathrm{L}_{2}$ - two months air-drying for stemwood and one month in pile; $\mathrm{W}_{3}$-transpirational drying during three months; $\mathrm{L}_{3}$-stemwood air-drying during three months.

\section{Discussion}

The results for density indicate that, for Scots pine small diameter roundwood, air-drying in piles (scenario C) is a better method than transpirational drying (scenario W) or air-drying of stemwood without limbs (scenario L). However, this depends on the storage period. Within one month of storage there were statistically significant differences between the two drying methods, in piles and by transpiration. Two months after harvesting was statistically significant differences between all methods. Within three months, the density of the roundwood stored in piles decreased to $700 \mathrm{~kg} / \mathrm{m}^{3}$, about $140 \mathrm{~kg} / \mathrm{m}^{3}$ more than in scenarios $\mathrm{W}_{3}$ and $\mathrm{L}_{3}$. In this case density of roundwood stored in the pile also was statistically significantly lower.

Within three months, the moisture content of the logs stored in piles decreased by 22.9 percentage points. With the transpirational drying method $(\mathrm{W})$ the decrease in moisture content was 10.0 percentage points. In scenario $\mathrm{L}$, at the end of the storage period the moisture content was lower by 15 percentage points. However, statistically significant differences between scenarios were not found. Nurmi and Hillebrand [20] showed that MC of Scots pine stemwood and whole trees, after one summer drying season is similar. They pointed, that this is because the processing of multi-tree bunches caused some debarking to take place. As a result, the transpirational drying capability of whole trees was equalized by the evaporation of moisture via the open wood surface. In the experiment, logs were harvested by conventional, motor-manual logging methods, with minimal bark damage. A critical factor determining the intensity of evaporation and the drying process is the open wood area, without bark $[18,19,21]$. Roundwood stored in piles had a greater open wood area than whole trees and 
stemwood without limbs. After the delimbing process small open wood area remain around knots. But they were too small and had no significant effect on the drying process. Perhaps for this reason, difference between scenarios W and L was not statistically significant. Moisture loss via the open wood surface was equalized by the transpiration. It is also interesting that there were no statistically significant differences compared to the MC of roundwood stored in a pile. Roundwood stored in piles had a much greater open wood area than logs, which was drying by other methods. However, in this case, this did not matter for MC either.

For MC and mass of logs, all methods are comparable, but were significant for density. MC strongly correlated with oven-dry density of wood. Coniferous are a classical example of changes of properties within-stem. A markedly lower density and higher MC is found in the top part of the tree trunk. This may explain the difference in green density of logs obtained different parts of the tree. Small diameter logs dry easier and faster than large logs [32-35]. At the beginning of the study higher MC and green density values were recorded for logs obtained from the top part of the tree trunk. After a three month of storage in a pile, the pattern was reversed. This means that logs obtained from the top part of the tree trunk dried more rapidly than logs obtained from the bottom part of the trunk. In our experiment transpirational drying proceeds more slowly than drying by other methods, and the presence of branches has a negative impact on the pattern of MC along the length of the trunk.

Some authors have pointed out that, in the initial phase of storage, transpirational drying is more effective; however, the longer the storage period, the less efficient this method becomes [23,25]. We are not able to confirm this statement because in the first month of storage the effectiveness of the methods was comparable. The design of the experiment did not provide for continuous or more frequent weight measurement. Perhaps, in the case of continuous or more frequent measurement, significant differences would be obtained. However, it was not the aim of this work to construct an exact model. In fact, the results obtained from this study are relatively unsophisticated because they do not account directly for weather trends, only for the storage duration and felling period. This is a simplification because it is unlikely that such high accuracy is reflected in the scheduling of industrial operations. Classical models based on weather data are expensive to build and somewhat difficult to use because they require exact knowledge of weather data on the part of the user.

Our case study demonstrates changes in moisture content and mass loss in specific conditions. In the experiment, stems were not protected from precipitation. Logs were harvested by conventional, motor-manual logging methods, with minimal bark damage. Moreover, the results are applicable only to the experienced weather conditions and storage duration, and may vary with other weather conditions and storage times. Generally the outcomes are comparable to those of other experiments. Irrespective of the method of storage, there was a gradual decrease in MC, mass, and density. Nonetheless, we obtained much valuable information which may be useful in the planning of supply chains. Efficiency is currently one of the key issues in supply chain management, for example, in the transport of energywood [38]. Natural drying methods are a simple way of reducing moisture content, which is a critical factor that determines the weight of roundwood or chipped wood [12,39-41] and, thus, strongly influences the costs of transportation [1]. Simulations show that the number of journeys can be significantly reduced, and vehicle payload significantly increased, when MC is lowered [5,6]. This is particularly important in the case of Scots pine, which accounts for a very high percentage of the small roundwood harvested in Poland.

\section{Conclusions}

In recent years, the number of studies on the optimization of energy and industrial wood transportation have rapidly increased [42-44]. Nevertheless, the analysis of relationships between methods of preparation, storage, and drying, and their influence on changes in the MC and weight of Scots pine logs, remains an important topic of study. The present study compared the most popular natural drying methods for stemwood: transpirational and air-drying. For MC and mass all methods are comparable. In each method, during storage, MC and mass decreased significantly. After three 
months, the initial moisture content above $50 \%$ can drop to between $27 \%$ and $35 \%$, making logs an excellent fuel. Mean mass of logs decreased from about $11 \mathrm{~kg}$ to about $8 \mathrm{~kg}$. Within three months, the density of the roundwood stored in piles was about $140 \mathrm{~kg} / \mathrm{m}^{3}$ less than other methods, what is important for transport efficiency. The best method of preparing Scots pine wood for drying is cutting it into short logs and storing them in piles. Moderate effects of drying were achieved for delimbed stemwood, and the least effective method was found to be transpirational drying.

Author Contributions: Conceptualization: A.T.; methodology: A.T.; formal analysis: K.T. and A.T.; data curation: K.T. and A.T.; writing—original draft preparation: K.T., A.T., and T.J.; writing-review and editing: A.T. and T.J.; visualization: K.T.; supervision: A.T. All authors have read and agreed to the published version of the manuscript.

Funding: Publication was co-financed within the framework of the Polish Ministry of Science and Higher Education's program: "Regional Initiative Excellence" in the years 2019-2022 (No. 005/RID/2018/19).

Acknowledgments: The authors would like to thank the staff of the Sieraków Forest Inspectorate for their help with the experiment and to an anonymous reviewer for commenting and improving scientific quality of this paper.

Conflicts of Interest: The authors declare no conflict of interest.

\section{References}

1. Ghaffariyan, M.R.; Acuna, M.; Brown, M. Analysing the effect of five operational factors on forest residue supply chain costs: A case study in Western Australia. Biomass Bioenergy 2013, 59, 486-493. [CrossRef]

2. Malladi, K.T.; Sowlati, T. Optimization of operational level transportation planning in forestry: A review. Int. J. For. Eng. 2017, 28, 198-210. [CrossRef]

3. Mydlarz, K.; Wieruszewski, M. Problems of Sustainable Transport of Large-Sized Roundwood. Sustainability 2020, 12, 2038. [CrossRef]

4. Stokes, B.J.; McDonald, T.P.; Kelley, T. Transpirational drying and costs for transporting woody biomass-A preliminary review. In Proceedings of the IEA/BA Task IX, Activity 6: Transport and Handling, Aberdeen University, Aberdeen, NB, Canada, 16-25 May 1994; pp. 76-91.

5. Erber, G.; Huber, C.; Stampfer, K. To split or not to split: Feasibility of pre-storage splitting of large poplar (Populus spp. L.) fuelwood logs. Fuel 2018, 220, 817-825. [CrossRef]

6. Erber, G.; Kanzian, C.; Stampfer, K. Modelling natural drying of European beech (Fagus sylvatica L.) logs for energy based on meteorological data. Scand. J. For. Res. 2016, 31, 294-301. [CrossRef]

7. Stokes, B.J.; Watson, W.F.; Miller, D.E. Transpirational Drying of Energywood; American Society of Agricultural Engineers Paper: St. Joseph, CA, USA, 1987; p. 14.

8. Erber, G.; Holzleitner, F.; Kastner, M.; Stampfer, K. Impact of Different Time Interval Bases on the Accuracy of Meteorological Data Based Drying Models for Oak (Quercus L.) Logs Stored in Piles for Energy Purposes. Croat. J. For. Eng. 2017, 38, 1-9.

9. Erber, G.; Kanzian, C.; Stampfer, K. Predicting moisture content in a pine logwood pile for energy purposes. Silva. Fenn. 2012, 46. [CrossRef]

10. Raitila, J.; Heiskanen, V.-P.; Routa, J.; Kolström, M.; Sikanen, L. Comparison of Moisture Prediction Models for Stacked Fuelwood. Bioenerg. Res. 2015, 8, 1896-1905. [CrossRef]

11. Routa, J.; Kolström, M.; Ruotsalainen, J.; Sikanen, L. Precision measurement of forest harvesting residue moisture change and dry matter losses by constant weight monitoring. Int. J. For. Eng. 2015, 26, 71-83. [CrossRef]

12. Krigstin, S.; Wetzel, S. A review of mechanisms responsible for changes to stored woody biomass fuels. Fuel 2016, 175, 75-86. [CrossRef]

13. Hakkila, P. Utilization of Residual Forest Biomass; Springer Series in Wood Science; Springer: Berlin/Heidelberg, Germany, 1989; ISBN 978-3-642-74074-9.

14. Wang, Z.; Zhou, Z.; Wang, X.; Chen, Z. Relationships between transpiration, water loss, and air conditions during physiological drying. Dry. Technol. 2018, 36, 245-254. [CrossRef]

15. Osonubi, O.; Davies, W.J. The influence of plant water stress on stomatal control of gas exchange at different levels of atmospheric humidity. Oecologia 1980, 46, 1-6. [CrossRef]

16. Tomczak, A.; Jelonek, T.; Leszczyński, N. Natural drying of wood in the cutting area. Sylwan 2017, 161, 898-908. [CrossRef] 
17. Röser, D.; Mola-Yudego, B.; Sikanen, L.; Prinz, R.; Gritten, D.; Emer, B.; Väätäinen, K.; Erkkilä, A. Natural drying treatments during seasonal storage of wood for bioenergy in different European locations. Biomass Bioenergy 2011, 35, 4238-4247. [CrossRef]

18. Visser, R.; Berkett, H.; Spinelli, R. Determining the effect of storage conditions on the natural drying of radiata pine logs for energy use. N. Z. J. Sci. 2014, 44, 3. [CrossRef]

19. Nurmi, J.; Lehtimäki, J. Debarking and drying of downy birch (Betula pubescens) and Scots pine (Pinus sylvestris) fuelwood in conjunction with multi-tree harvesting. Biomass Bioenergy 2011, 35, 3376-3382. [CrossRef]

20. Nurmi, J.; Hillebrand, K. The characteristics of whole-tree fuel stocks from silvicultural cleanings and thinnings. Biomass Bioenergy 2007, 31, 381-392. [CrossRef]

21. Defo, M.; Brunette, G. A log drying model and its application to the simulation of the impact of bark loss. For. Prod. J. 2006, 56, 8.

22. Anisimov, P.; Onuchin, E.; Vishnevskaja, M. Modeling Pine and Birch Whole Tree Drying. Croat. J. For. Eng. 2017, 38, 11-17.

23. McMinn, J.W. Transpirational drying of red oaks, sweetgum, and yellow-poplar in the Upper Piedmont of Georgia. For. Prod. J. 1986, 36, 25-27.

24. Rogers, K.E. Preharvest drying of logging residues. For. Prod. J. 1981, 31, 32-36.

25. Cutshall, J.B.; Greene, W.D.; Baker, S.A. Transpirational Drying Effects on Energy and Ash Content from Whole-Tree Southern Pine Plantation Chipping Operations. South. J. Appl. For. 2013, 37, 133-139. [CrossRef]

26. Gislerud, O. Drying and storing of comminuted wood fuels. Biomass 1990, 22, 229-244. [CrossRef]

27. Filbakk, T.; Høibø, O.A.; Dibdiakova, J.; Nurmi, J. Modelling moisture content and dry matter loss during storage of logging residues for energy. Scand. J. For. Res. 2011, 26, 267-277. [CrossRef]

28. Wetzel, S.; Volpe, S.; Damianopoulos, J.; Krigstin, S. Can Biomass Quality Be Preserved through Tarping Comminuted Roadside Biomass Piles? Forests 2017, 8, 305. [CrossRef]

29. Labbé, R.; Carey, P.; Trincado, G.; Thiers, O. Natural drying of forest biomass: Effect of stack height and cover in the province of Valdivia, Chile. Bosque (Valdivia) 2018, 39, 449-456. [CrossRef]

30. Tomczak, A.; Grodziński, G.; Jakubowski, M.; Jelonek, T.; Grzywiński, W. Effects of Short-Term Storage Method on Moisture Loss and Weight Change in Beech Timber. Croat. J. For. Eng. 2018, 39, 35-43.

31. Saralecos, J.; Keefe, R.; Tinkham, W.; Brooks, R.; Smith, A.; Johnson, L. Effects of Harvesting Systems and Bole Moisture Loss on Weight Scaling of Douglas-Fir Sawlogs (Pseudotsuga Menziesii var. glauca Franco). Forests 2014, 5, 2289-2306. [CrossRef]

32. Abbot, P.; Lowore, J.; Khofi, C.; Werren, M. Defining firewood quality: A comparison of quantitative and rapid appraisal techniques to evaluate firewood species from a southern African savanna. Biomass Bioenergy 1997, 12, 429-437. [CrossRef]

33. Röser, D.; Erkkilä, A.; Mola-Yudego, B.; Sikanen, L.; Prinz, R.; Heikkinen, A.; Kaipainen, H.; Oravainen, H.; Hillebrand, K.; Emer, B.; et al. Natural Drying Methods to Promote Fuel Quality Enhancement of Small Energywood Stems; Working Papers; Finnish Forest Research Institute: Vantaa, Finland, 2010; p. 60.

34. Brand, M.A.; Muñiz, G.I.B.D.; Brito, J.O.; Quirino, W.F. Influence of size and shape of forest biomass, stored in piles, on quality of wood fuel. Rev. Árvore 2014, 38, 175-183. [CrossRef]

35. Lee, D.; Choi, J. Estimating Wood Weight Change on Air Drying Times for Three Coniferous Species of South Korea. J. For. Environ. Sci. 2016, 32, 262-269. [CrossRef]

36. Grochowski, J. Dendrometry; PWRiL: Warsaw, Poland, 1973.

37. EN. ISO 18134-2 Solid Biofuels-Determination of Moisture Content-Oven Dry Method-Part Two: Total Moisture—Simplified Method; International Organization for Standardization: Geneva, Switzerland, 2017.

38. Acuna, M.; Anttila, P.; Sikanen, L.; Prinz, R.; Asikainen, A. Predicting and Controlling Moisture Content. Croat. J. For. Eng. 2012, 33, 225-238.

39. Spinelli, R.; Magagnotti, N.; Paletto, G.; Preti, C. Determining the impact of some wood characteristics on the performance of a mobile chipper. Silva. Fenn. 2011, 45. [CrossRef]

40. Routa, J.; Kolström, M.; Ruotsalainen, J.; Sikanen, L. Validation of Prediction Models for Estimating the Moisture Content of Small Diameter Stem Wood. Croat. J. For. Eng. 2015, 36, 283-291.

41. Pecenka, R.; Lenz, H.; Hering, T. Options for Optimizing the Drying Process and Reducing Dry Matter Losses in Whole-Tree Storage of Poplar from Short-Rotation Coppices in Germany. Forests 2020, 11, 374. [CrossRef] 
42. Rafael, S.; Tarelho, L.; Monteiro, A.; Monteiro, T.; Gonçalves, C.; Freitas, S.; Lopes, M. Atmospheric Emissions from Forest Biomass Residues to Energy Supply Chain: A Case Study in Portugal. Environ. Eng. Sci. 2015, 32, 505-515. [CrossRef]

43. Tymendorf, Ł.; Trzciński, G. Multi-Factorial Load Analysis of Pine Sawlogs in Transport to Sawmill. Forests 2020, 11, 366. [CrossRef]

44. Kanzian, C.; Kühmaier, M.; Erber, G. Effects of Moisture Content on Supply Costs and CO2 Emissions for an Optimized Energy Wood Supply Network. Croat. J. For. Eng. 2016, 37, 51-60.

(C) 2020 by the authors. Licensee MDPI, Basel, Switzerland. This article is an open access article distributed under the terms and conditions of the Creative Commons Attribution (CC BY) license (http://creativecommons.org/licenses/by/4.0/). 